\title{
Antioxidant Effect of Melatonin in Human Retinal Neuron Cultures
}

\author{
Min-Cheol Lee, ${ }^{* 1}$ Y oung-Taek Chung,† J ae-Hyuk Lee,* J ong-J ae J ung,‡ \\ Hyung-Seok Kim,ł and Seung U. Kim§ \\ *Department of Pathology, Chonnam National University Medical School and Research Institute of Medical Sciences; \\ †Department of Ophthalmology, School of Medicine, Chonbuk National University; łDepartment of Pathology, \\ College of Medicine, Seonam University; and §Brain Disease Research Center, Ajou University
}

Received October 31, 2000; accepted J uly 17, 2001

This study investigates whether the neurohormone melatonin can prevent the retinal neuronal injury caused by reactive oxygen species (ROS) in cultured human retinal neuronal cells. Cultures of human retinal neuronal cells established from a variety of donors were grown to 14 days and then subjected to experimental hypoxanthine/xanthine oxidase (HX/ XO)-induced injury. Intracellular production of ROS by administration of HX/XO was confirmed by flow cytometry; the ROS resulted in both apoptotic and necrotic pattern of cell death in the retinal neuron cultures. The efficacy of melatonin against ROS injury was quantitated by MTT assay, enzyme immunoassay, and immunocytochemistry for neurofilament protein. The antioxidative effect of melatonin was compared with that of $\alpha$-tocopherol. Retinal neuronal injury significantly reduced in a dose-response manner by a treatment of 1.0-8.0 $\mathrm{mM} \alpha$-tocopherol. Melatonin, in concentrations of more than $\mathbf{2 . 0} \mathrm{mM}$, also significantly reduced the injury. About $70 \%$ of cells are rescued by pretreatment with $1.0 \mathrm{mM} \alpha$-tocopherol and $8.0 \mathrm{mM}$ melatonin in the MTT assay. Our observations suggest that melatonin can rescue retinal neurons from ROS injury in human retinal cell cultures. 02001 Elsevier Science

Key Words: antioxidant; melatonin; MTT assay; neurofilament protein; retinal neurons; ROS (reactive oxygen species).

\section{INTRODUCTION}

The chemical identity of the neurohormone melatonin, $\mathrm{N}$-acetyl-5-methoxy-tryptamine, was reported in the late 1950 s as a secretory product of the pineal gland (18). The central nervous system was thought to be a primary target organ of melatonin which mediates

\footnotetext{
${ }^{1}$ To whom correspondence should be addressed at Department of Pathology, Chonnam National University Medical School, 5 Hakdong, Dong-ku, Kwangju 501-190, Korea. Fax: 82-62-227-3429. Email: mclee@chonnam.ac.kr.
}

a variety of physiological and behavioral processes, including biological circadian rhythms and neuroendocrine and immunologic functions $(19,21,24)$. Melatonin is increasingly promoted as a therapeutic agent for the treatment of jet lag and insomnia (20). While production of melatonin in higher vertebrates mainly occurs in the pineal gland, extrapineal melatonin synthesis was identified in the retina, the Harderian glands, and the gastrointestinal tract (15). Moreover, melatonin exerts its regulatory roles through high-affinity and G-protein coupled receptors that reside primarily in the eye, kidney, gastrointestinal tract, blood vessels, and brain (2).

Oxygen is necessary for aerobic cellular reactions; however, it may undergo electron transfer reactions resulting in the generation of highly toxic intermediates, such as superoxide $\left(\mathrm{O}_{2}^{-}\right)$, hydrogen peroxide $\left(\mathrm{H}_{2} \mathrm{O}_{2}\right)$, or the hydroxyl radical $(\cdot \mathrm{OH})$. These reactive oxygen species (ROS) inflict significant oxidative damage to membrane lipids (36). Xanthine oxidase (XO) has been established as an important source of oxygen free radicals in ischemia-reperfusion $(6,26)$. Superoxide radical and hydrogen peroxide are products of the oxidation of xanthine or hypoxanthine $(\mathrm{HX})$ catalyzed by XO $(9,16)$. These oxygen radicals may also interact with trace amounts of iron to produce hydroxyl radicals $(11,12)$. This system has been established in the pathogenetic mechanism of stroke (3). In the human eye, XO was detected in the endothelial cells of the retinal capillaries and calbindin-positive cone cells by immunohistochemistry on frozen sections (8).

Recent studies indicated a role of melatonin related to antioxidant activity $(6,26,36)$. Melatonin can protect from oxidative injury by scavenging the hydroxyl radical and peroxyl radical and inhibiting XO, a cellular source of cytotoxic superoxide radicals. Retinal injury from ROS is implicated in many ophthalmology diseases $(13,28,31)$. With such considerations in mind, we investigated the protective role of melatonin against HX/XO-mediated oxygen radical injury in human retinal neuron cultures. A well-known antioxi- 
TABLE 1

Clinical Information of Donors for Retinal Cell Cultures

\begin{tabular}{rrrlcr}
\hline Serial No. & Age & Sex & \multicolumn{1}{c}{ Cause of death } & Enucleation after death $(\mathrm{h})$ & Culture after enucleation (h) \\
\hline 1 & 27 & F & Head injury & 2 & 14 \\
2 & 38 & M & Intracerebral hemorrhage & 3 & 20 \\
3 & 35 & F & Subarachnoid hemorrhage & 3 & 21 \\
4 & 31 & M & Chest and multiple organ injury & 2 & 17 \\
5 & 39 & F & Head injury & 2 & 15 \\
6 & 36 & F & Head injury & 4 & 24 \\
7 & 21 & M & Head injury & 3 & 19 \\
8 & 25 & M & Multiple chest injury & 4 & 24 \\
9 & 29 & F & Head injury & 5 & 30 \\
10 & 35 & M & Head injury & 3 & 23 \\
\hline
\end{tabular}

dant, $\alpha$-tocopherol, was also tested in the culture system, and the antioxidant effect was compared with that of melatonin.

\section{MATERIALS AND METHODS}

\section{Primary Cell Culture}

Retinal tissues from 10 individual donors were obtained from the Eye Bank of Chonnam National University Hospital (Table 1). The time elapsed between each donor's time of death and the isolation of retina for culture ranged from 14 to $30 \mathrm{~h}$. After the removal of corneal and scleral tissues, remaining globes were stored in bottles containing media at $4^{\circ} \mathrm{C}$ and transported to the laboratory for tissue culture.

Following coronal section of the gl obe at the equatorial plane, the vitreous body was removed. The retina was peeled off from the pigment epithelium and other ocular tissue, and placed in Hanks' balanced salt solution (BSS). The retina was minced into small pieces of tissue with two scal pels. Retinal tissue fragments were incubated in 10-ml tubes, containing $3 \mathrm{ml}$ serum-free Eagle's minimum essential medium (MEM) and $70 \mathrm{U}$ activated papain, for $40 \mathrm{~min}$ at $37^{\circ} \mathrm{C}$. Papain was activated by addition of $5 \mathrm{mg}$ cysteine (Sigma, St. Louis, MO) into stock solution (90 U/ml) and used for enzymatic digestion after filtration through a Milipore filter $(45 \mu \mathrm{m})$. After incubation, enzyme-treated clumps of tissue were dissociated into single cells by gentle pipetting. Cells were suspended in feeding medium consisting of MEM containing $10 \%$ fetal bovine serum (FBS), $0.5 \%$ glucose, and $20 \mu \mathrm{g} / \mathrm{ml}$ gentamicin. The cells were plated at a density of $1 \times 10^{6} \mathrm{cell} \mathrm{s} / \mathrm{ml}$ in $75-\mathrm{cm}^{2}$ culture flasks and incubated in a $5 \% \mathrm{CO}_{2} / 95 \%$ air atmosphere at $37^{\circ} \mathrm{C}$.

Two-thirds of the medium was changed every 5 days. Cells were cultured until a confluent basal layer of astrocytes formed (10-14 days) with an adhering layer of small spherical or bipolar neurons (Fig. 1A). In order to obtain neuron-enriched populations, the feeding medium was replaced with fresh medium. Neurons grow- ing on the surface of the astrocytes were detached by mechanical shaking throughout overnight on an orbital shaker at $250 \mathrm{rpm}$. Enriched neurons (>90\% purity), ovoid or round cells showing $\sim 5-8 \mu \mathrm{m}$ in diameter with neurofilament protein (NE 14, Sigma, St Louise, MO)-positive unipolar or bipolar neurites, were harvested, centrifuged, and seeded on 96-well multichamber plates at a cell density of $1 \times 10^{4}$ cells per well. For immunocytochemical evaluation, dissociated cells were seeded on poly-L-lysine-coated (Sigma) Aclar plastic coverslips ( $9 \mathrm{~mm}$ in diameter) at cell density of $1 \times 10^{3}$ cells per coverslip. The coverslips were placed inside of culture dishes (60 mm in diameter). For measurement of ROS and DNA electrophoresis, the enriched neurons were seeded onto 24-well plates at a density of $5 \times 10^{5} \mathrm{cell} / \mathrm{s} / \mathrm{cm}^{2}$. Cultures were incubated in a $5 \% \mathrm{CO}_{2} / 95 \%$ air incubator at $37^{\circ} \mathrm{C}$, and two-thirds of the medium was replaced with fresh medium once a week. The neuron-enriched cultures were recultured for 5 days and subsequently used for the experiments.

\section{Exposure to Oxygen Radicals}

Hypoxanthine, xanthine oxidase, melatonin, and $\alpha$-tocopherol were obtained from Sigma. Melatonin and $\alpha$-tocopherol were prepared as $100 \mu \mathrm{g} / \mathrm{ml}$ concentrated stock solutions in 3\% absolute ethanol and diluted directly into the culture medium at concentrations of $0.5,1.0,2.0,4.0$, and $8.0 \mathrm{mM}$. The cultures were washed three times with exposure medium (17), the composition of which follows $(\mathrm{mM}): \mathrm{CaCl}_{2}(2.50), \mathrm{KCl}$ (5.00), $\mathrm{NaCl}$ (137.0), $\mathrm{KH}_{2} \mathrm{PO}_{4}$ (0.3), $\mathrm{NaHCO}_{3}$ (4.0), $\mathrm{NaHPO}_{4}(0.3)$, glucose (5.6), glycine (0.01), and Hepes (10.0). Melatonin and $\alpha$-tocopherol were added to cultures $2 \mathrm{~h}$ prior to oxygen radical injury. Oxygen radical generation was initiated by addition of $100 \mu \mathrm{M} \mathrm{HX}$ and 5- $40 \mathrm{mU} / \mathrm{ml}$ XO for $4 \mathrm{~h}$ in exposure medium. After $4 \mathrm{~h}$ of exposure to $\mathrm{HX} / \mathrm{XO}$ with or without melatonin, $\alpha$-tocopherol, or both, cultures were washed, fed with $10 \%$ FBS containing normal feeding medium, and incubated for $2 \mathrm{~h}$. Upon completion of the experiments, 

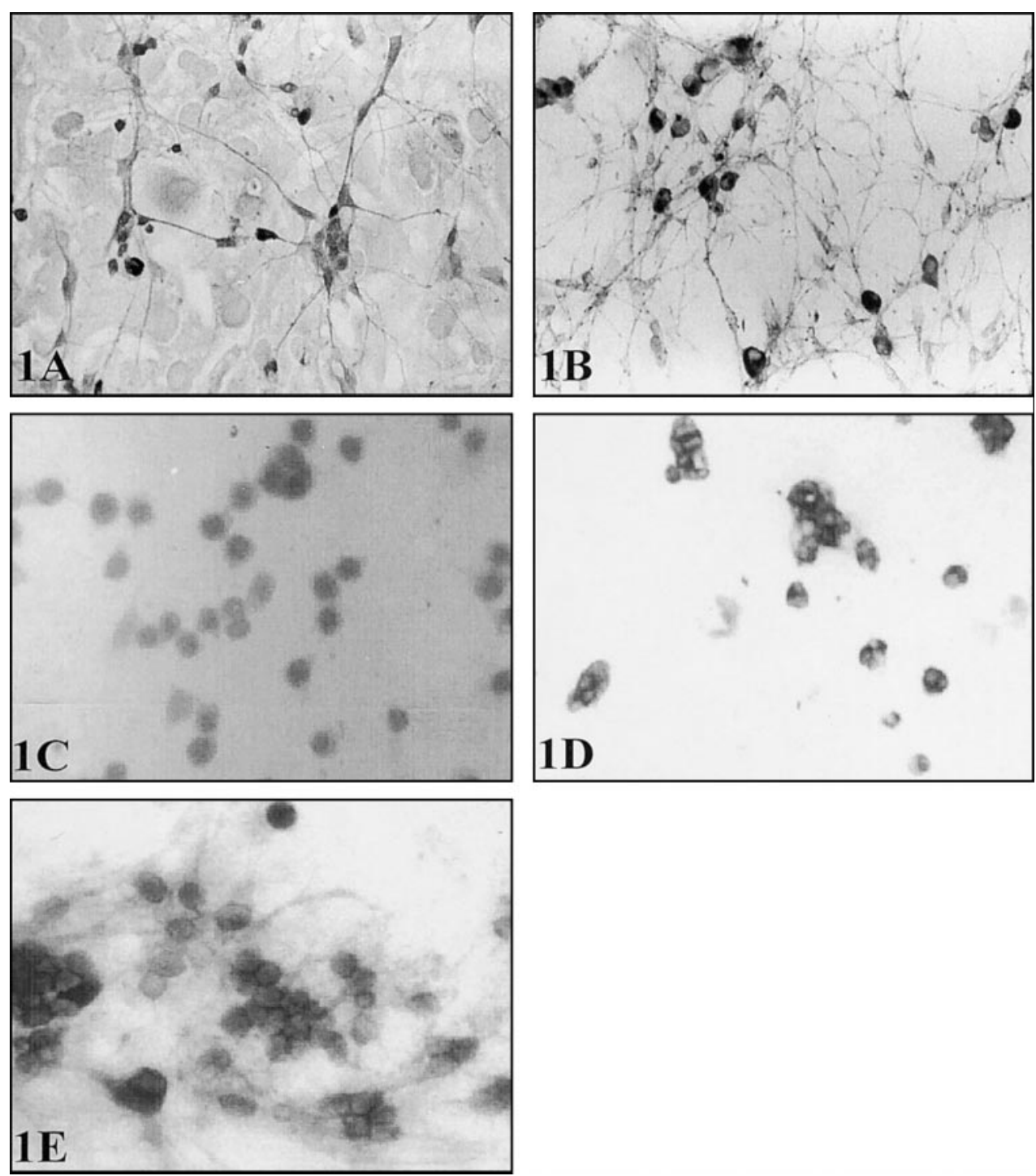

FIG. 1. Cytologic features of human retinal neuron cultures with NF immunohistochemistry $(\times 200)$. A number of small neurons with uni- or bipolar neurites appeared on the layer of astrocytes (A). Neuron-enriched culture consisted of small neurons with delicate neurites (B). Retinal neurons exposed to HX/XO revealed loss of neurites with nuclear pyknosis (C), and NF immunoreactivity gradually disappeared in severely damaged neurons by HX/XO injury (D). Retinal neurons were rescued from $\mathrm{HX} / \mathrm{XO}$ exposure by pretreatment of melatonin. Note relatively intact neuronal cell body and neurites (E).

cultures were processed for cytotoxicity assays and immunocytochemical examinations.

\section{Cytologic Examinations by Light Microscope}

Cultures on Aclar coverslips were examined under a phase-contrast inverted microscope and processed for immunocytochemistry for neurofilament proteins using the avidin-biotin-peroxidase complex (ABC) method (14). Cultures were washed once with PBS and fixed in 4\% paraformaldehyde for $5 \mathrm{~min}$. Following two washes with PBS containing $0.2 \%$ Triton X-100, cultures were incubated with murine monoclonal antibody specific for $150-\mathrm{kDa}$ neurofilament proteins (NE 14, Sigma) for $60 \mathrm{~min}$, followed by biotin-labeled goat anti-mouse antibody for $30 \mathrm{~min}$ in avidin- biotinperoxidase (Research Genetics, Huntsville, AL) for 30 min, and then with diaminobenzidine tetrahydrochloride (DAB) chromogen. Viability of the cultured neurons was also determined by light microscopy with the MTT (3-4,5-dimethylthiazol-2-yl-2,5-diphenyl tetrazolium bromide; Sigma) assay.

\section{Cytotoxicity Assay}

In order to measure viability and integrity of the cultured cells, the MTT assay and the neurofilament protein immunoassay (NF-EIA) were used in this study. The MTT assay was carried out by the Mosman method (25). MTT was dissolved in PBS at $5 \mathrm{mg} / \mathrm{ml}$ and 
filtered through a membrane filter (45 $\mu \mathrm{m}$ in diameter) to sterilize, and stored at $4^{\circ} \mathrm{C}$ in an aluminum foil sealed tube to prevent light exposure. Following addition of MTT stock solution (10 $\mu$ l per $100 \mu \mathrm{l}$ medium) into wells, the plates were incubated for $4 \mathrm{~h}$ at $37^{\circ} \mathrm{C}$. After incubation, acid-isopropanol $(0.04 \mathrm{~N} \mathrm{HCl}$ in isopropanol) was added to all wells, and the plates were read on a micro-ELISA reader at a wave length of 570 $\mathrm{nm}$.

NF-EIA was performed as follows. Cultured cells in 96-well plates were washed twice with PBS and fixed with methyl alcohol for $15 \mathrm{~min}$ at $-20^{\circ} \mathrm{C}$. After one wash with PBS containing $0.2 \%$ Triton X-100, cells were incubated with monoclonal antibody specific for 150-kDa neurofilament protein (NE 14, 1:100, Sigma) followed by goat anti-mouse IgG conjugated with horseradish peroxidase (1:200, Sigma) for $1 \mathrm{~h}$ each at room temperature. After three washes in PBS, citrate buffer containing $0.04 \%$ O-phenylenediamine (Sigma) and $0.02 \%$ hydrogen peroxide was added to all wells and incubated for $5 \mathrm{~min}$ in the dark. To stop the reaction, $2 \mathrm{~N} \mathrm{HCl}$ was added to wells and the 96-well plates were read on a micro-ELISA reader at a wave length of $490 \mathrm{~nm}$. Statistical comparisons were performed by ANOVA and TUKEY methods.

\section{Measurement of ROS}

To investigate the correlation between the injury of retinal neurons and ROS production, the intracellular levels of ROS were measured by flow cytometry using 6-carboxy-2', 7'-dichlorodihydrofluorescein diacetate (CDCDHF-DA, Molecular Probes, Eugene, OR), a fluorogen responsive to superoxide and other ROS (32). CDCDHF-DA was added to cell cultures grown in 24well plates to a final concentration of $10 \mu \mathrm{M}$ for $30 \mathrm{~min}$ at $37^{\circ} \mathrm{C}$, and then $5-40 \mathrm{mU} / \mathrm{ml} \times O$ was added to the medium with or without $100 \mu \mathrm{M} \mathrm{HX}$. To determine antioxidative effect in the experiment $\sim 1-8 \mathrm{mM}$ melatonin and $\alpha$-tocopherol were added to the cultures $2 \mathrm{~h}$ prior to administration of $100 \mu \mathrm{M} \mathrm{HX/20} \mathrm{mU/ml} \mathrm{XO.}$ After $1 \mathrm{~h}$, the cells were collected and analyzed by flow cytometry. Linearized fluorescence levels were used as an indicator of the production of ROS, when the control fluorescence level (HX only) was corrected at $100 \%$.

\section{DNA Electrophoresis}

To determine the types of cell death, apoptosis or necrosis, by $\mathrm{HX} / \mathrm{XO}$-generated oxygen radical cytotoxicity on retinal neuron cultures, the pattern of the DNA fragmentation was evaluated. For DNA electrophoresis, cellular DNA was havested from the cultures exposed to $20 \mathrm{mU} / \mathrm{ml} \mathrm{XO}$ and $100 \mu \mathrm{M} \mathrm{HX}$ for $20 \mathrm{~min}, 1 \mathrm{~h}$, and $2 \mathrm{~h}$. DNA was isolated and purified by the DNA isolation kit (Puregene, Minneapolis, MN). The DNA (5 $\mu \mathrm{g} /$ lane) was electrophoresed on an apoptosis ladder detection kit (Wako, Osaka, J apan) containing 1.5\% agarose gel and ethidium bromide at $50 \mathrm{~V}$ for $5 \mathrm{~h}$. The DNA was visualized under ultraviolet light and photographed.

\section{RESULTS}

\section{Cytologic Findings of Retinal Neuron Cultures}

At 5 days, on phase contrast microscopy of human retinal neuronal cells growing in exposure medium supplemented with $10 \%$ FBS showed neurons bearing round cell bodies and fine, delicate branching neurites. Uni- or bipolar neurons of the outer and inner nuclear layers and a few large ganglion cells were observed. Neuronal injury induced by $\mathrm{HX} / \mathrm{XO}$ began with mild retraction of cell bodies and loss of neurites, demonstrated by an administration of $100 \mu \mathrm{M} \mathrm{HX}$ and 5 $\mathrm{mU} / \mathrm{ml}$ XO for $1 \mathrm{~h}$ in cultures.

In neurofilament protein immunocytochemistry, positive signal was noted in the perinuclear cytoplasm of neurons and neurites in intact cells (Fig. 1B). In injured cells, loss of stainability was identified in neurites after an administration of $\mathrm{HX} / \mathrm{XO}$ (Fig. 1C). Although neurites disappeared, NF immunoreactivity persisted or decreased in the cytoplasm of some pyknotic neurons. NF immunoreactivity gradually disappeared in severely damaged neurons (Fig. 1D). The cytotoxic injury, caused by an administration of $\mathrm{HX} /$ $\mathrm{XO}$, was significantly reduced by pretreatment of melatonin and/or $\alpha$-tocopherol.

Light microscopic examination of the cultures, previously processed for MTT assay, showed abundant fibrillary depositions of bluish insoluble formazan pigment in cell bodies and neurites in the control group (Fig. 2A). However, there were fewer depositions of bluish pigment with many unstained ghost cells in the $\mathrm{HX} / \mathrm{XO}$-treated group (Fig. 2B). Cultures exposed to $\mathrm{HX} / \mathrm{XO}$ plus $\alpha$-tocopherol revealed less reduction in stainability. The neuronal cytoarchitecture was relatively well preserved against $\mathrm{HX} / \mathrm{XO}$ injury by pretreatment of $\alpha$-tocopherol and more than $2 \mathrm{mM}$ melatonin (Fig. 2C).

\section{HXIXO-Induced Cytotoxicity}

To evaluate the dose-response relationship of $\mathrm{HX} /$ XO-generated cytotoxicity on retinal neurons, cultures were exposed to $100 \mu \mathrm{M} \mathrm{HX}$ plus XO at concentrations of $5,10,20$, or $40 \mathrm{mU} / \mathrm{ml}$ for $4 \mathrm{~h}$ and processed for MTT assay (Fig. 3). At $5 \mathrm{mU} / \mathrm{ml} \times 0,76.4 \%$ of cells survived after $4 \mathrm{~h}$ of exposure. At 10, 20, and $40 \mathrm{mU} / \mathrm{ml} \mathrm{XO}$, cell survival was markedly reduced to 57.6, 50.1, and $40.6 \%$ of control, respectively (F ig. 3). The concentration of XO to cause cell death in $50 \%\left(L_{50}\right)$ was found to be $20 \mathrm{mU} / \mathrm{ml} X O$. Subsequent studies were conducted on a combination of $20 \mathrm{mU} / \mathrm{ml} \mathrm{XO}$ and $100 \mu \mathrm{M}$ $\mathrm{HX}$. The time course of $\mathrm{HX} / \mathrm{XO}$-induced cytotoxicity in 

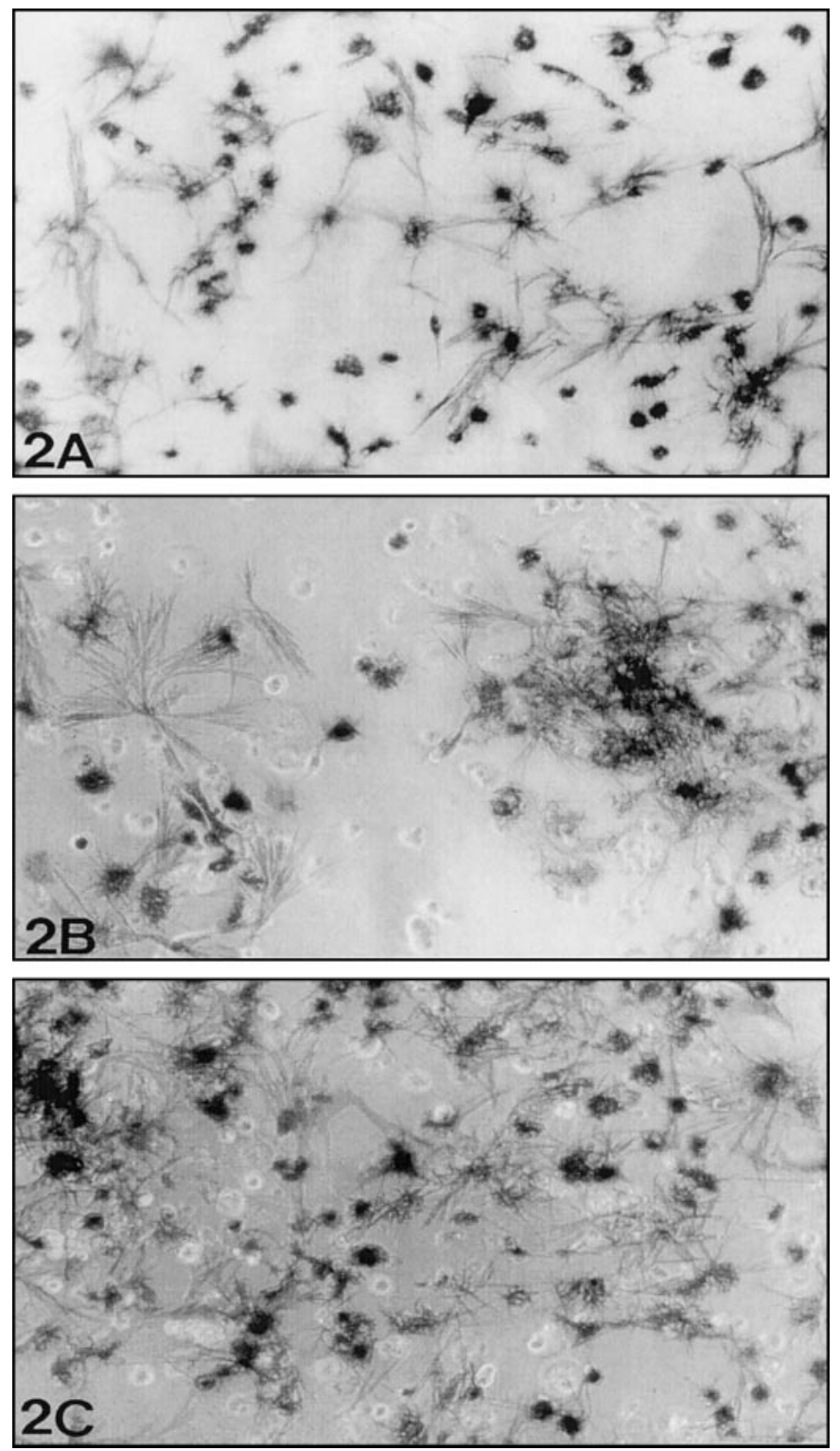

FIG. 2. MTT assay revealed significantly altered viability of retinal neuronal cells; $\mathrm{HX}$ only $(A), H X / X O(B)$, melatonin $+H X / X O(C)$.

retinal neurons is shown in Fig. 4. At $20 \mathrm{mU} / \mathrm{ml} \mathrm{XO}$, the cell viability was $83.4 \%$ after $1 \mathrm{~h}$ of exposure, $65.7 \%$ after $2 \mathrm{hr}, 56.8 \%$ after $3 \mathrm{~h}$, and $48.8 \%$ after $4 \mathrm{~h}$ of exposure to the $\mathrm{HX} / \mathrm{XO}$ system ( $\mathrm{Fig}$. 4). The adequate exposure time of the retinal neurons required to produce an optimal injury by $\mathrm{HX} / \mathrm{XO}$ was $4 \mathrm{~h}$.

\section{Oxygen Radical Production by HX/XO}

To examine the involvement of ROS by HX/XO-induced retinal neuronal injury, flow cytometric analysis for C-DCDHF-DA was performed. C-DCDHF-DA did not increase in the absence of $\mathrm{HX}$. In presence of 100 $\mu \mathrm{M} \mathrm{HX}, \mathrm{C}$-DCDHF-DA fluorescence increased after addition of $\mathrm{XO}$. The fluorescence increased in response to

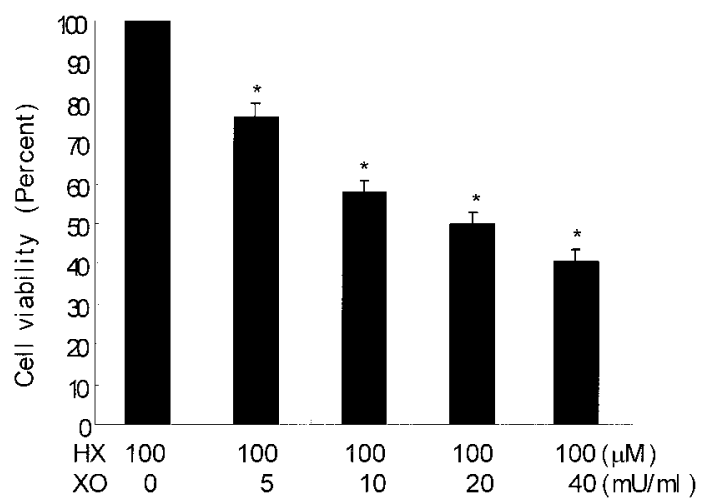

FIG. 3. Dose-response relationship of HX/XO-induced cytotoxicity in the human retinal neuron cultures. The cultures were exposed to $100 \mathrm{mM} \mathrm{HX}$ and 5, 10, 20, $40 \mathrm{mU} / \mathrm{ml}$ XO for $4 \mathrm{~h}$. The proportion of viable cells was measured by MTT assay. Cell viability decreased significantly with addition of $5 \mu \mathrm{U} / \mathrm{ml} \mathrm{XO}$, and about $50 \%$ of viability resulted from administration of $100 \mathrm{mM} \mathrm{HX}$ plus 20- $40 \mathrm{mU} / \mathrm{ml} \mathrm{XO}$. (Data represent mean $\pm S D$ for five experiments. $* P<0.01 ; H X$, hypoxanthine; $\mathrm{XO}$, xanthine oxidase.)

concentrations of XO, and it measured 141.3, 187.1, 235.6, and $337.8 \%$ at $5,10,20,40, \mathrm{mU} / \mathrm{ml}$ XO, respectively ( $P<0.01, \mathrm{Fig}$. 5). The increased fluorescence by the $\mathrm{HX} / \mathrm{XO}$ system correlated well with the cytotoxic injury in the retinal neuron cultures. In the pretreatment of $1,2,4$, and $8 \mathrm{mM}$ melatonin $2 \mathrm{~h}$ prior to administration of $100 \mu \mathrm{M} \mathrm{HX/20} \mathrm{mU} \mathrm{XO,} \mathrm{the} \mathrm{relative}$ intensity of fluorscence was 216.1, 198.4, 171.5, $159.6 \%$, respectively. In the pretreatment of the same concentrations of $\alpha$-tocopherol, the relative intensity of fluorescence was 213.6, 190.7, 170.3, and 148.9\% each other (Fig. 6). The fluorescence intensity was significantly reduced by pretreatment of 4 and $8 \mathrm{mM}$ meltonin, and 2, 4, and $8 \mathrm{mM} \alpha$-tocopherol $(\mathrm{P}<0.01)$.

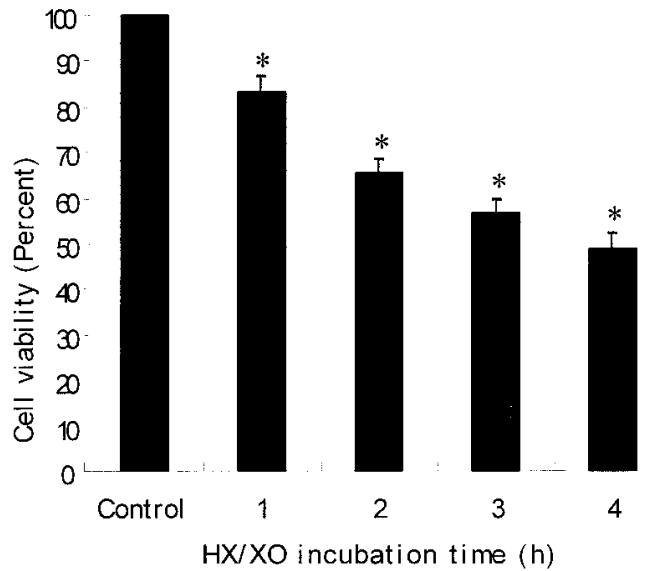

FIG. 4. HX/XO-induced cytotoxicity over time in the human retinal neuron cultures. The cultures were exposed to $100 \mu \mathrm{M} \mathrm{HX}$ and $20 \mathrm{mU} / \mathrm{ml} \mathrm{XO}$ for 1, 2, 3, and $4 \mathrm{~h}$. The proportion of viable cells was measured by MTT assay. Cell viability decreased significantly after $1 \mathrm{~h}$, and less than $50 \%$ of cells were viable after $4 \mathrm{~h}$. (Data represent mean $\pm \mathrm{SD}$ for five experiments. $* \mathrm{P}<0.01 ; \mathrm{HX}$, hypoxanthine; $\mathrm{XO}$, xanthine oxidase.) 


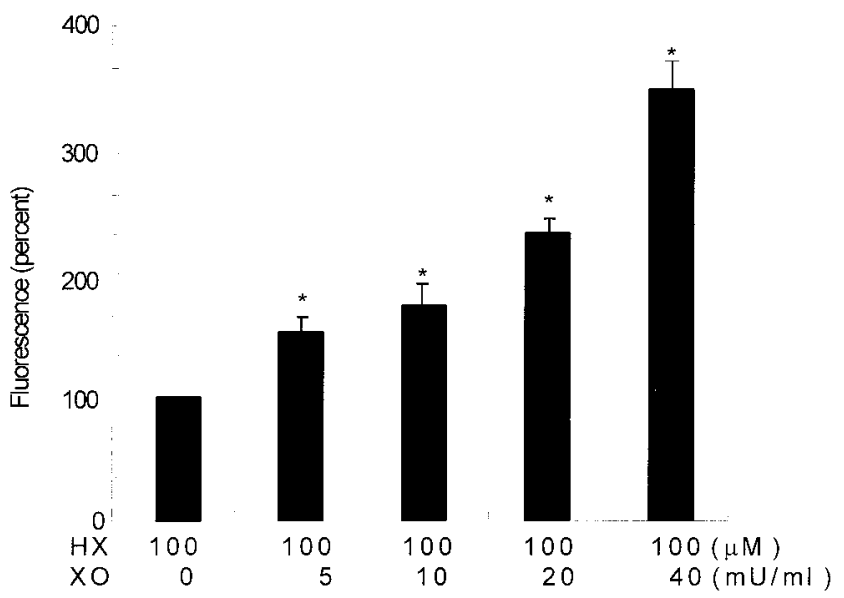

FIG. 5. Oxygen radical production by administration of $H X / X O$. Dose-dependent enhancement of C-DCDHF-DA fluorescence induced by $100 \mu \mathrm{M} \mathrm{HX}$ and 5, 10, 20, $40 \mathrm{mU} / \mathrm{ml} \mathrm{XO}$ after $1 \mathrm{~h}$ in the retinal neuron cultures. (Data represent mean \pm SD for five experiments. $* \mathrm{P}<0.01 ; \mathrm{HX}$, hypoxanthine; XO, xanthine oxidase.)

\section{Types of Cell Death by DNA Electrophoresis}

To examine the types of cell death in the retinal cultures, necrosis or apoptosis, DNA agarose gel electrophoresis was performed. It revealed a diffuse smear pattern in cultures exposed to $100 \mu \mathrm{M} \mathrm{HX}$ and 20 $\mathrm{mU} / \mathrm{ml} \times \mathrm{O}$ for $1 \mathrm{~h}$ or more. A characteristic ladder pattern was observed in cultures exposed to $100 \mu \mathrm{M}$ $\mathrm{HX}$ and $20 \mathrm{mU} / \mathrm{ml} \mathrm{XO}$ for $20 \mathrm{~min}$ (Fig. 7).

\section{Protective Effects of $\alpha$-Tocopherol and Melatonin against Oxygen Radical Injury}

The neuroprotective effects of $\alpha$-tocopherol and melatonin were examined in retinal neuron cultures

300

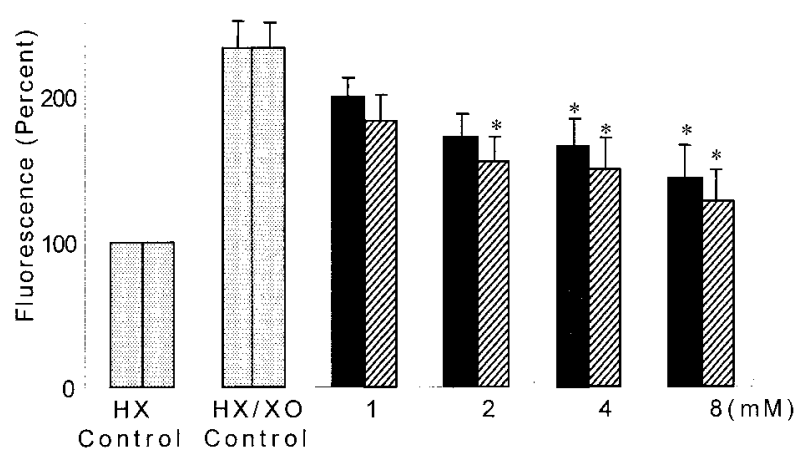

FIG. 6. Effects of melatonin and $\alpha$-tocopherol against oxygen radical injury evaluated by flow cytometry for C-DCDHF-DA fluorescence. Pretreatment of melatonin $(4,8 \mathrm{mM})$, and $\alpha$-tocopherol (2, 4, $8 \mathrm{mM}$ ) reduced C-DCDHF-DA fluorescence induced by $100 \mu \mathrm{M}$ $\mathrm{HX} / 20 \mathrm{mU} / \mathrm{ml} \mathrm{XO}$ for $1 \mathrm{~h}$ in the human retinal cultures. (Data represent mean $\pm \mathrm{SD}$ for five experiments. $* \mathrm{P}<0.01 ; \mathrm{HX}$, hypoxanthine; $\mathrm{XO}$, xanthine oxidase.)

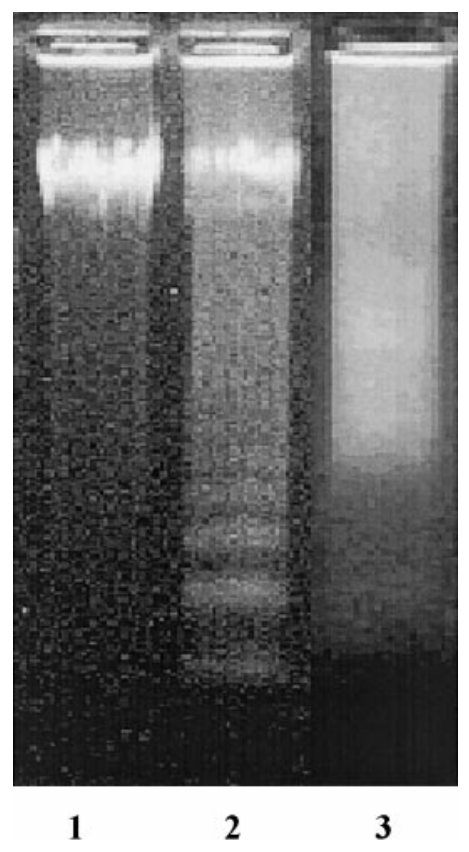

FIG. 7. DNA electrophoresis revealed a characteristic ladder pattern in the cultures exposed to $100 \mu \mathrm{M} \mathrm{HX}$ and $20 \mu \mathrm{M}$ XO for 20 min (lane 2); however, DNA was diffusely smeared in the cultures exposed the $\mathrm{HX} / \mathrm{XO}$ for more than $1 \mathrm{~h}$ (lane 3).

against oxygen radical-induced neurotoxicity. Results were determined by MTT assay and NF-EIA. In the positive control, approximately $50 \%$ of the cells survived after $4 \mathrm{~h}$ of treatment with $100 \mu \mathrm{M} \mathrm{HX}$ plus 20 $\mathrm{mU} \times \mathrm{X}$ (Fig. 8).

Addition of $0.5,1.0,2.0,4.0$, and $8.0 \mathrm{mM} \alpha$-tocopherol resulted in cell viability of $65.8,75.8,84.2,89.9$, and $90.9 \%$, respectively, against $\mathrm{HX} / \mathrm{XO}$-induced neurocytotoxicity $(50.5 \%)$ for $4 \mathrm{~h}(\mathrm{P}<0.001)$. Melatonin 
melatonin

W-tocopherol

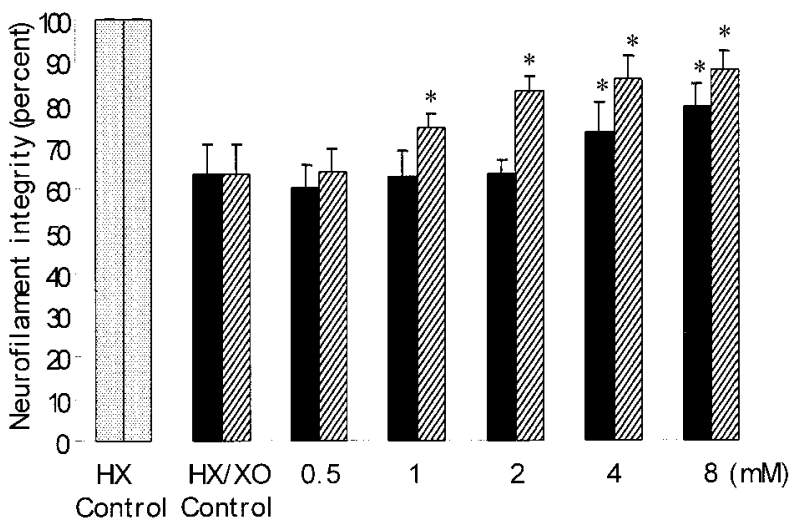

FIG. 9. Effects of melatonin and $\alpha$-tocopherol against oxygen radical injury evaluated by NF-EIA. The density of neurofilament protein was markedly reduced by administration of $100 \mu \mathrm{M} \mathrm{HX/20}$ $\mathrm{mU} / \mathrm{ml} \mathrm{XO}$. Cytotoxicity was inhibited by $4 \mathrm{~h}$ pretreatment of $4-8$ $\mathrm{mM}$ melatonin and 1-8 $\mathrm{mM} \alpha$-tocopherol. (Data represent mean \pm SD for five experiments. ${ }^{*} \mathrm{P}<0.01 ; \mathrm{NF}-\mathrm{EI} A$, neurofilament protein enzyme immunoassay; $\mathrm{HX}$, hypoxanthine; $\mathrm{XO}$, xanthine oxidase.)

showed $66.3,72.7$, and $77.3 \%$ cell viability at concentrations of 2, 4, and $8 \mathrm{mM}$, respectively, against $\mathrm{HX} /$ XO-induced neurotoxicity $(P<0.001)$. No significant protection was appreciated at concentrations of 0.5 and $1.0 \mathrm{mM}$ melatonin.

The neuroprotective effect of melatonin and $\alpha$-tocopherol against $\mathrm{HX} / \mathrm{XO}$-induced cytotoxicity in the retinal cultures was also determined by NF-EIA (Fig. 9). $\alpha$-Tocopherol showed NF density of 74.5, 83.3, 85.1, and $87.8 \%$ at concentrations of $1,2,4$, and $8 \mathrm{mM}$, respectively, while $\mathrm{HX} / \mathrm{XO}$ administration revealed $63 \%$ ( $P<0.001$ ). Melatonin revealed NF density of 73.1 and $79.1 \%$ at concentrations of 4 and $8 \mathrm{mM}$, respectively $(\mathrm{P}<0.001)$.

In the combination pretreatment of $\alpha$-tocopherol and melatonin against $\mathrm{HX} / \mathrm{XO}$-induced cytotoxicity in the retinal cultures, the neuroprotective effect and resulted $\sim 1.7-3.6 \%$ higher by MTT assay and $\sim 2.3-$ $4.0 \%$ higher by NF-EFA than $\alpha$-tocopherol pretreatment. The neuroprotective effect was slightly increased by the combination treatment of melatonin and $\alpha$-tocopherol; however, the synergistic effects was not statistically significant $(P>0.05)$.

\section{DISCUSSION}

Administration of $\mathrm{HX} / \mathrm{XO}$ in this experimental culture system produced ROS, and resulted in apoptotic and necrotic cell death which was evidenced by flow cytometry and DNA electrophoresis, respectively. Relative to other organs of body, the nervous system may be especially vulnerable to ROS-mediated injury due to a number of biochemical, physiological, and anatomical characteristics of neurons: high rate of oxidative metabolic activity, high concentration of readily oxidizable polyunsaturated fatty acids in membranes, endogenous generation of ROS by specific neurochemical re actions, high ratio of cell surface area to volume, neuroanatomical network vulnerable to disruption, and nonreplicating character of neuronal cells (7). The retina is a part of the central nervous system (CNS), and its injury from ROS has been implicated in several ophthalmologic diseases $(6,16,26,36)$.

The present experiments were carried out on mixed cultures of human retinal neurons consisting of photoreceptor cells in the outer nuclear layer (ONL), amacrine, bipolar, and horizontal neurons in the inner nuclear layer (INL) and ganglion cells in the ganglion cell layer. Even the heterogeneity or polymorphism of cultured neuronal cells in this experiment could be demonstrated by cytologic features; the majority of cells (>90\%) were composed of small uni- or bipolar neurons.

Pretreatment with melatonin or $\alpha$-tocopherol in cultured human retinal neurons resulted in neuroprotective effect against $\mathrm{HX} / \mathrm{XO}$-mediated ROS injury. In the MTT assay, more than $2 \mathrm{mM}$ melatonin was required to rescue the retinal neurons from the injury, whereas $0.5 \mathrm{mM} \alpha$-tocopherol provided protection. When evaluated by NF-EIA, more than $4 \mathrm{mM}$ melatonin or $1 \mathrm{mM}$ $\alpha$-tocopherol protected the retinal neurons. There were slight differences in cell viability between the MTT assay and the NF-EIA method.

In the comparision of cell viability, NF-EIA revealed narrower neuroprotective values of melatonin and $\alpha$-tocopherol than the MTT assay. This might be caused by the differce in the cytologic findings of the two assay methods. MTT is a yellow water-soluble tetrazolium dye that is reduced by live, but not dead, cells to a bluish purple formazan product that is insoluble in aqueous solutions (25). This assay offers the advantage of staining only viable cells. In contrast, NF immunocytochemistry revealed loss of immunoreactivity in neuronal cell processes primarily due to ROS injury. A few degenerated neurons still expressed NF immunoreactivity. The cytochemical staining characteristics could be responsible for the differing sensitivities in evaluation of cell viability of this experiment.

The action mechanisms of $\alpha$-tocopherol and melatonin against ROS injury are slightly different. $\alpha$-Tocopherol is a lipid-soluble antioxidant concentrated in the hydrophobic interior of cell membranes (30). It is known to contribute an electron to the peroxyl radical that is generated in the chain reaction of lipid peroxidation and is classified as a chain-breaking antioxidant or scavenger of ROS in lipid cell membrane.

Melatonin has been reported to be a direct scavenger of the highly toxic hydroxyl radical (36) and to have other antioxidant activities both in vitro and in vivo. Melatonin readily passes through the blood-brain bar- 
rier (29) and enters neurons and glial cells (23). Exogenously administered melatonin quickly enters cells, distributes in all subcellular compartments, and accumulates in the nucleus because of its lipid and water solubility (4). Other studies indicate that melatonin is an effective scavenger of both hydroxyl and peroxyl radicals in the cell membrane, a stimulator of GSH peroxidase in cytosol, and an efficient protector of nuclear DNA (1). These findings suggest that melatonin is an antioxidant with multiple protective effects. Many studies have supported the dramatic protective effects of melatonin against ROS injury induced by a variety of agents: paraquat (22), lipopolysaccharide (34), carbon tetrachloride (5), kainic acid (10), alloxan (27), Fenton reagents (33), and ischemia-reperfusion injury of the CNS (3).

In terms of an antioxidant effect against $\mathrm{HX} / \mathrm{XO}$, $\alpha$-tocopherol has a greater neuroprotective effect than melatonin. The concentration of each agent required for $70 \%$ cell viability were 1 and $4 \mathrm{mM}$ for $\alpha$-tocopherol and melatonin, respectively. This result was supported by a study recently performed in rat retinal homogenates (35). Treatment with $\alpha$-tocopherol yielded a lower level of ROS products than did the same concentration of melatonin. Nonetheless, melatonin can rescue retinal neurons from ROS injury generated by HX/ $\mathrm{XO}$, the pharmacological antioxidative effect of melatonin in human retina should be further investigated.

\section{REFERENCES}

1. Acuna-Castroviejo, D., A. Coto-Montes, M. G. Monti, G. G. Ortiz, and R. J . Reiter. 1997. Melatonin is protective against MPTP-induced striatal and hippocampal lesions. Life Sci. 60: PL23-29.

2. Beyer, C. E., J. D. Steketee, and D. Saphier. 1998. Antioxidant properties of melatonin: An emerging mystery. Biochem. Pharmacol. 56: 1265-1272.

3. Braughler, J . M., and E. D. Hall. 1989. Central nervous system trauma and stroke. Free Radic. Biol. Med. 6: 289-301.

4. Cagnoli, C. M., C. Atabay, E. Kharlamova, and H. Manev. 1995. Melatonin protects neurons from singlet oxygen-induced apoptosis. J . Pineal Res. 18: 222-226.

5. Daniels, W. M. W., R. J. Reiter, D. Melchiorri, E. Sewerynek, M. I. Pablos, and G. G. Ortiz. 1995. Melatonin counteracts lipid peroxidation induced by carbon tetrachloride but does not restore glucose-6-phosphatase activity. J . Pineal Res. 19: 1-16.

6. Dykens, J . A., A. Stern, and E. Trenkner. 1987. Mechanisms of kainate toxicity to cerebellar neurons in vitro is analogous to reperfusion tissue injury. J . Neurochem. 409: 1222-1228.

7. Evans, P. H. 1993. Free radicals in brain metabolism and pathology. Brit. Med. Bulletin. 49: 577-587.

8. Fox, N. E., and F. J . van Kuijk. 1998. Immunohistochemical localization of xanthine oxidase in human retina. Free Radic. Biol. Med. 24: 900-905.

9. Fridovich, I. 1978. The biology of oxygen radicals. Science 201: 875- 880.

10. Giusti, P., M. Lipartiti, D. Franceschini, N. Schiavo, M. Floreani, and $\mathrm{H}$. Manev. 1996. Neuroprotection by melatonin from kainate-induced excitotoxicity in rats. FASEB J . 10: 891- 896.
11. Graf, E., J. R. Mahoney, R. G. Bryant, and J . W. Eaton. 1984. I ron-catalyzed hydroxyl radical formation: Stringent requirement for free iron coordination site. J . Biol. Chem. 259: 36203624.

12. Harber, F., and J. Weiss. 1934. The catalytic decomposition of hydrogen peroxide by anion salts. Proc. R. Soc. London A. 147: 333-351.

13. Hollis, A. L., W. I. Butcher, H. Davis, R. A. Henderson, and W. L. Stone. 1992. Structural alterations in retinal tissues from rats deficient in vitamin $\mathrm{E}$ and selenium and treated with hyperbaric oxygen. Exp. Eye Res. 54: 671- 684.

14. Hsu, S. M., L. Raine, and H. Fanger. 1981. Use of avidin-biotinperoxidase complex $(A B C)$ in immunoperoxidase techniques: $A$ comparison between $A B C$ and unlabeled antibody (PAP) procedures. J . Histochem. Cytochem. 29: 577-580.

15. Huether, G. 1993. The contribution of extrapineal sites of melatonin synthesis to circulating melatonin levels in higher vertebrates. Experimentia 49: 665-670.

16. Kellogg, E. W., and I. Fridovich. 1977. Liposome oxidation and erythrocyte lysis by enzymatically generated superoxide and hydrogen peroxide. J . Biol. Chem. 252: 6721- 6728.

17. Kikuchi, S., H. Muramatsu, T. Muramatsu, and S. U. Kim. 1993. Midkine, a novel neurotrophic factor, promotes survival of mesencephalic neurons in culture. Neurosci. Lett. 160: 9-12.

18. Krause, D. N., and M. L. Dubocovich. 1990. Regulatory sites in the melatonin system of mammals. Trends Neurosci. 13: 464470.

19. Lehrer, S. 1979. Possible pineal-suprachiasmatic regulation of development and life-span. Arch. Ophthalmol. 97: 359-365.

20. Marshall, K. A., R. J . Reiter, B. Poeggeler, O. I. Aruoma, and B. Halliwell. 1996. Evaluation of the antioxidant activity of melatonin in vitro. Free Radic. Biol. Med. 21: 307-315.

21. Meites, J . 1990. Aging: Hypothalamic catecholamines, neuroendocrine-immune interactions, and dietary restriction. Proc. Soc. Exp. Biol. Med. 195: 304-311.

22. Melchiorri, D., R. J. Reiter, A. M. Attia, M. Hara, A. Burgas, and G. Nistico. 1995. Potent protective effect of melatonin on in vivo paraquat-induced oxidative damage in rats. Life Sci. 56: 83- 89.

23. Menendez-Pelaez, A., B. Poeggeler, R. J . Reiter, L. Barlow-Walden, M. I. Pablos, and D. X. Tan. 1993. Nudear localization of melatonin in different manmalian tissues: Immunocytochemical and radioimmunoassay evidence. J . Cell. Biochem. 53: 373-382.

24. Miller, J. D. 1992. Pharmacological intervention in sleep and circadian processes. Annu. Rep. Med. Chem. 27: 11-19.

25. Mosman, T. 1983. Rapid colorimetric assay for cellular growth and survival: Application to proliferation and cytotoxic assay. J . Immunol. Methods 65: 55- 63.

26. Pieri, C., M. Marra, F. Moroni, R. Reschioni, and F. Marcheselli. 1995. Melatonin: A peroxyl radical scavenger more effective than vitamin E. Life Sci. 55: PL271-276.

27. Pierrefiche, G., and H. Laborit. 1995. Oxygen radicals melatonin and aging. Exp. Gerontol. 30: 213-227.

28. Rao, N. A. 1990. Role of oxygen free radicals in retinal damage associated with experimental uveitis. Trans. Am. Ophthalmol. Soc. 88: 797-850.

29. Reiter, R., L. Tang, J.J . Garcia, and A. Munoz-Hoyos. 1997. Pharmacological actions of melatonin in oxygen radical pathophysiology. Life Sci. 60: 2255-2271.

30. Reiter, R. J . 1995. Oxidative processes and antioxidative defense mechanisms in the aging brain. FASEB J . 9: 526-533.

31. Reiter, R. J . 1996. Novel intracellular actions of melatonin: Its relation to reactive oxygen species. In Melatonin: A Universal Photoperiodic Signal with Diverse Actions (P. L. Tang, S. F. 
Pang, and R. J . Reiter, Eds.), Vol. 21, pp.160-166. Front Horm Res. Karger, Basel.

32. Satoh, T., N. Sakai, Y. Enokido, Y. Uchiyama, and H. Hatanaka. 1996. Free radical-independent protection of PC12 cells from hydrogen peroxide-triggered death by nerve growth factor and the bcl-2 gene product. J . Biochem. (Tokyo) 120: 540-546.

33. Sewerynek, E., D. Melchiorri, G. G. Ortiz, B. Poeggeler, and R. J . Reiter. 1995. Melationin reduces $\mathrm{H}_{2} \mathrm{O}_{2}$ induced lipid peroxidation in homogenates of different rat brain regions. J. Pineal Res. 19: 51-56.
34. Sewerynek, E., D. Melchiorri, R. J . Reiter, G. G. Ortiz, and A. J . Lewinski. 1995. Lipopolysaccharide-induced hepatotoxicity is inhibited by the antioxidant melatonin. Eur. J . Pharmacol . 293: 327-334.

35. Siu, A. W., R. J. Reiter, and C. H. To. 1998. The efficacy of vitamin $\mathrm{E}$ and melatonin as antioxidants against lipid peroxidation in rat retinal homogenates. J . Pineal Res. 24: 239-244.

36. Tan, D. X., L. D. Chen, B. Poeggeler, L. C. Manchester, and R. J . Reiter. 1993. Melatonin: A potent, endogenous hydroxyl radical scavenger. Endocr. J . 1: 57-60. 